\title{
School experiences and young women's pregnancy and parenthood decisions: a systematic review and synthesis of qualitative research
}

\begin{abstract}
Schools are considered high-potential environments for promoting adolescent sexual and reproductive health outcomes among young women. Qualitative studies provide context and meaning to how school experiences and systems contribute to pregnancy and parenthood decisions from the perspectives of youth. This systematic review screened 24,711 references from 8 databases, yielding 28 qualitative studies. Included studies were assessed for quality and synthesised using meta-ethnographic approaches. Reciprocal translation revealed that young women's life trajectories were at least partially shaped by a commitment to school values and expectations for academic achievement, influenced by structural and relational factors within the school. These findings resonate with Markham and Aveyard's theory of human functioning and school organisation. Future policy and practices might seek to improve teacher-student interactions, leverage young women's developing autonomy, and ensure physically and psychologically safe spaces for students.
\end{abstract}

\section{Keywords}

Schools, adolescent health, sexual behaviour, systematic review, qualitative

\section{Highlights}

- Systematic review and synthesis of 28 qualitative studies revealed that young women's life trajectories were at least partially shaped by a commitment to school values and expectations for academic achievement.

- Young women's life and educational aspirations fit into their perceptions of how education or parenthood would help them achieve adulthood status.

- Young women indicated the ways that schools shaped their commitment to school and education, including whether school values were representative of their cultural identities and how teachers' explicit or implicit messages affected their expectations for future education or career.

\section{Funding}

This research did not receive any specific grant from funding agencies in the public, commercial, or not-for-profit sectors. 


\section{Introduction}

In adolescence, young women experience biological, cognitive and social transitions that influence health behaviours and outcomes in adolescence and adulthood (Sawyer et al., 2012). While there is debate that becoming an adolescent parent affects workforce participation and income earnings (Ashcraft et al., 2013; Fletcher and Wolfe, 2009), evidence suggests that adolescent parenthood disrupts girls' educational trajectories while highlighting the economic and mental health benefits of delaying parenthood into adulthood (Sonfield et al., 2013). Pregnancy rates among 15-19 year-old girls in the U.S. are higher than any other country with available data (Sedgh et al., 2015), and 75\% of pregnancies are unintended (Finer and Zolna, 2016). Further, unintended pregnancy and sexual behaviours that lead to pregnancy disproportionately affect low-income, rural and minority youth (Centers for Disease Control and Prevention, 2015; Ng and Kaye, 2015; Penman-Aguilar et al., 2013). Even with progress over the last 20 years (Martin et al., 2015), inequities in adolescent pregnancy and parenthood call for strategies that address upstream determinants of sexual and reproductive health.

Next to the home, young people spend most of their time interacting with peers and staff in school (Kaftarian et al., 2004). Therefore, schools are high-potential environments for supporting healthy development and fostering educational assets associated with health, such as academic success and optimism for future opportunities (Freudenberg and Ruglis, 2007; Muennig and Woolf, 2007; Viner et al., 2012). Access to education may be particularly important for promoting young women's sexual health (Patton et al., 2016). Current governmental strategies on adolescent pregnancy have prioritized the implementation of 'evidence-based programmes' in school settings, most of which focus on changing individual knowledge and attitudes (Koh, 2014). However, these interventions may not effectively influence upstream determinants (Rose, 1992; Viner et al., 2012), failing to address inequities in sexual risk behaviour experienced by socially-disadvantaged youth.

In their theory of human functioning and school organisation (Figure 1), Markham and Aveyard (2003) suggest that schools can increase health-promoting behaviours by improving students' commitment to schools' instructional (i.e., promoting knowledge and skills) and regulatory (i.e., promoting character and good conduct) orders and hence their capacity for practical reasoning and positive affiliations with other students. To improve student commitment, the authors propose schools should strengthen relationships among staff and 
students, adopt instructional and regulatory practices that are student-centred, and erode cultural boundaries between schools and local communities.

Figure 1. Theory of human functioning and school organization (Markham and Aveyard, 2003) The health literature provides evidence that school influences adolescent health behaviour. Multiple studies indicate that school-based interventions influence sexual behaviours that lead to pregnancy by addressing school-level (Basen-Engquist et al., 2001; Flay et al., 2004; Patton et al., 2006) and individual-level (Allen et al., 1997; Flay et al., 2004; Patton et al., 2006; Philliber et al., 2002) determinants related to school environment and educational assets. Longitudinal studies report that attitude to school, school engagement, school connectedness and educational expectations or aspirations correlate with reduced adolescent pregnancy or birth, delayed sexual initiation and activity, and increased condom or contraceptive use (Bonell et al., 2005; Kogan et al., 2013; Markham et al., 2010; Rink et al., 2007; White and Warner, 2015). Few multilevel model studies have examined whether school-level factors, such as attending school with high levels of school connectedness, impacts school-level reproductive outcomes and have produced mixed results (Henderson et al., 2008; White and Warner, 2015).

Qualitative studies can make critical contributions to policy and practice by exploring the context and meaning of school experiences from young women's perspectives (Green and Thorogood, 2013). Previous reviews examined adolescent pregnancy and parenting but did not explicitly explore school or education themes (Spear and Lock, 2003), or did not address school experiences prior to pregnancy (Graham and McDermott, 2005). Harden et al. (2009) reviewed research with socially disadvantaged young parents, including attitude to school prior to pregnancy. This review was limited to U.K. studies and is now several years old. Jamal et al (2013) synthesised qualitative research as a part of a mixed-methods review on the school environment and student health outcomes, including two studies covering sexual health. However, several important studies were missed and analysis did not focus on sexual health. The current review builds upon these reviews to address the research question how are school and education experiences implicated in young women's accounts of their attitudes and actions relating to sex, contraception, pregnancy and parenthood? 


\section{Methods}

This study follows PRISMA guidelines for conducting and reporting systematic reviews.

Modifications to the review protocol (Peterson and Bonell, 2016) are identified in Table 1.

Additional details are provided in supplemental materials.

\begin{tabular}{|l|l|}
\hline Inclusion Criteria & $\begin{array}{l}\text { First inclusion criteria was modified during screening phase to } \\
\text { exclude studies that reported on sexual health education but not } \\
\text { broader school and education experiences. The timing did not impact } \\
\text { the likelihood of missed studies during the screening phases. }\end{array}$ \\
\hline Search Strategy & $\begin{array}{l}\text { Three additional databases were added (ProQuest Dissertations and } \\
\text { Theses Global, British Education Index (EBSCO), and Australian } \\
\text { Education Index (ProQuest). }\end{array}$ \\
\hline Data Extraction & $\begin{array}{l}\text { Single extraction of data by first author due to time and resource } \\
\text { constraints. }\end{array}$ \\
\hline Quality Assessment & $\begin{array}{l}\text { Single assessment of quality by first author due to time and resource } \\
\text { constraints. }\end{array}$ \\
\hline Synthesis & None. \\
\hline
\end{tabular}

Table 1. Deviations from protocol

\section{Inclusion Criteria}

To be included, studies had to: 1) report on accounts of school and education experiences as they related to sex, contraception, pregnancy and parenthood during adolescence (ages 10-19 years) as a major theme; 2) have a sample of at least $50 \%$ female participants; 3) employ qualitative data collection and analysis methods; and 4) be published in 1990 or later.

\section{Search and Screening Strategy}

Electronic databases (Medline, CINAHL Plus, PscyhINFO, ERIC, Web of Science Core Collection, ProQuest Dissertations and Theses Global, British and Australian Education Indexes) were searched in early 2016 using index and free-text terms. Search terms covered three concepts informed by previous reviews on school environment (Bonell et al., 2011) and qualitative research (Evans, 2002; Flemming and Briggs, 2007; Rees et al., 2010; Wong et al., 2004): 1) school/education OR adolescent AND 2) sexual behaviour, pregnancy OR parenthood AND 3) qualitative research. Several rounds of searches were piloted by the first author to assess precision and specificity. The final strategy was adapted (e.g., MeSH terms removed) and documented for each database. Additional studies were derived from web-based searches, 
reference checking of included studies and subject-matter expert contacts. The first author conducted all screening.

Figure 2. Screening Process and Outcomes

\section{Data Extraction}

Data were extracted on study aims, location, participant characteristics and study methods. Participant characteristics included: proportion female, age at time of data collection, race or ethnicity and socio-economic status as described in the study, and pregnant or parenting status. Methods included: study design, sampling (frame, selection, recruitment, and consent), data collection and analysis. The first author piloted the extraction tool on five studies, then extracted from remaining studies.

\section{Quality Assessment}

Critical appraisal was piloted and executed by the first author using the EPPI-Centre Tool (Rees et al., 2010; Shepherd, J et al., 2010). Each study was assigned two sets of scores (low, medium, or high) based on reliability and usefulness. Reliability is the extent to which researchers employed appropriate methods (e.g., study design, sampling, data collection, analysis) for their stated aims. Usefulness captures the relevance and conceptual richness that the study contributed to the review's research question, including breadth and depth of findings and the extent to which participant views were privileged.

\section{Synthesis}

Synthesis was conducted using meta-ethnographic approaches for translating findings across qualitative studies informed by Noblit and Hare (1988) and Thomas and Harden (2008).

Synthesis was conducted in three phases. Phase 1 was conducted by the first author. Phases 2 and 3 were conducted initially by the first author, then extended and refined by the first and second authors.

Phase 1: Studies were ordered by their reliability and usefulness scores then placed in chronological order. Studies were read and re-read to identify themes and concepts inductively, 
and coded in NVivo 11. Reciprocal translation of studies occurred by identifying common concepts and themes which were applied across studies in a third read.

Phase 2: Descriptive meta- and sub-themes were developed by grouping thematic codes with direct quotes supporting the theme from the review studies. Synthesis of descriptive themes occurred by identifying and summarizing themes that: conformed and extended across studies (i.e., reciprocal synthesis); built upon each other to create a logical argument (i.e., line-ofargument synthesis); or conflicted (i.e., refutational synthesis) (Noblit and Hare, 1988). These descriptive meta- and sub-themes are presented in the results section.

Phase 3: The descriptive meta- and sub-themes were compared and applied to the theory of human functioning and school organisation and existing evidence on school-related determinants of adolescent pregnancy, resulting in analytical themes that address the review aim. These analytical themes are presented in the discussion.

\section{Results}

A total of 24,711 records were screened using EPPI-Reviewer 4 (Thomas, J et al., 2010) on title and abstract and 589 studies on full text (Figure 2). Twenty-eight studies were included in the synthesis (Table 2). The majority were from the U.S. and U.K. Fifteen studies included pregnant or parenting teens, five included participants who were never pregnant as teens and nine studies did not explicitly include or exclude participants based on pregnancy or parenting status. Most studies targeted their sample based on socioeconomic status, race or ethnicity.

Quality assessment resulted in six low-quality, eight medium-quality and twelve highquality studies. Low-quality scores were primarily due to weaknesses in reporting methods. Studies rated most useful were high- or medium-quality. No study was excluded based on quality. In post-synthesis assessment, mostly high- and medium-quality studies contributed to theme development, though some detail would be lost if low-quality studies had been excluded. No theme was generated solely by a low-quality study.

Two major themes emerged in relation to adolescent sexual behaviour, pregnancy or parenthood, including young women's views on 1) their personal educational trajectories and; 2) their experiences with school and education. Reciprocal translation revealed that few studies discussed sexual behaviour, while most emphasised the impact of school or education on pregnancy or parenthood decisions. 


\section{Meta-theme 1: Young women's views and attitudes on educational and life trajectories}

In the first meta-theme, reciprocal translation revealed the role of life trajectories on sexual behaviour and pregnancy decisions as a central theme. Multiple authors framed this theme as a class issue, in which most middle-class, white adolescents favoured higher education pathways and financial independence prior to parenthood. The educational and life plans of low-income, youth of colour were more diverse (Elley, 2011; Vetter et al., 2011), and included higher education, as well as young parenthood and earlier entrance into the workforce (Arai, 2003; Bettie, 2003; Biggs et al., 2013; Coleman and Cater, 2006; Elley, 2011; Erdmans and Black, 2015; Smith and Roberts, 2011; Vetter et al., 2011; Walkerdine et al., 2001).

Sub-theme 1a: For many educationally-committed teens, adolescent pregnancy meant the disruption to educational and financial achievement.

Many teens who were not pregnant or parenting cited educational goals as a reason for avoiding pregnancy (Algert, 2000; Bayer et al., 2010; Childs et al., 2015; Gilbert, 2011; Hoskins, 2001; Martyn and Hutchinson, 2001; Noone et al., 2014; Tabi, 1999; Walkerdine et al., 2001; Willemsen and DeJaeghere, 2015). Educational goals were achieved by what Elley (2011, p. 423) described as 'regulating their sexual identities with their aspirations' through avoiding sex (Bayer et al., 2010; Willemsen and DeJaeghere, 2015) or using contraception (Elley, 2011; Martyn and Hutchinson, 2001). Where these methods failed, unintended pregnancies were resolved through abortion to preserve educational trajectories and social status, especially if the teen was middle-class (Arai, 2003; Coleman and Cater, 2006; Gilbert, 2011; Martyn and Hutchinson, 2001; Smith and Roberts, 2011; Walkerdine et al., 2001).

Sub-theme 1b: Educationally-committed teens framed their trajectories as pathways to responsible adulthood.

Higher education, career development and financial independence signalled the transition from adolescence to adulthood for educationally-committed teens (Bettie, 2003; Elley, 2011; Erdmans and Black, 2015; Walkerdine et al., 2001). Educational pathways were positioned as 'responsible' and teen pregnancy as 'immature,' these being viewed as incompatible. In a study on neverpregnant-or-parenting Puerto Rican teens, a $9^{\text {th }}$ grade focus group participant described the incompatibility of adolescence and parenthood: 'We are babies. We are not for having babies ... 
you have to understand you have a baby you have to be responsible to it' (Gilbert, 2011, p. 137). Responsibility included regulating reproduction because of its effects on education and career goals. In a 2001 study on African-American adolescents who avoided pregnancy (Martyn and Hutchinson, 2001), participants were described as 'tough girls' who altered negative scripts about race, teen parenthood and education:

Being responsible for their own destinies and relying on inner resolve and strength enabled the girls to follow their visions and adhere to their goals... Lisa explained, "There are choices, you can either have the baby, you can have it up for adoption, you can abort it, you can do whatever, but it completely falls on you..."(2001, p. 248).

Sub-theme 1c: Pregnancy and childbirth do not disrupt life trajectories for teens who do not view education as a realistic or desirable option.

Reciprocal translation revealed that most pregnant and parenting teens had weak attachment to school prior to pregnancy (Algert, 2000; Arai, 2003; Biggs et al., 2013; Dawson and Hosie, 2005; Erdmans, 2012; Erdmans and Black, 2015; Kaplan, 1997; Minnis et al., 2013; Noone et al., 2014; Zachry, 2005). Adopting middle-class values of 'going away to college' (Bettie, 2003, p. 71) was generally undesirable because they disliked school (Arai, 2003; Coleman and Cater, 2006; Dawson and Hosie, 2005; Erdmans, 2012; Hoskins, 2001) and perceived limited career options (Agogbuo, 2006; Algert, 2000; Arai, 2003; Coleman and Cater, 2006; Kaplan, 1997; Minnis et al., 2013; Smith and Roberts, 2011). For some, higher education was viewed as impossible because they lacked the academic skills or grades (Elley, 2011; Walkerdine et al., 2001) and because of financial and immigration-related barriers (Biggs et al., 2013; Minnis et al., 2013). Authors suggested that alternatives to universities, such as community college and vocational school, were economically limiting in the same ways young parenthood might be (Bettie, 2003; Kaplan, 1997).

Fewer prospects for social mobility may have removed barriers from pursuing romantic relationships that included unprotected sex (Elley, 2011) or from fulfilling a desire for motherhood (Arai, 2003). This aligned with an apparent variability in contraceptive trust and use (Arai, 2003; Bettie, 2003; Walkerdine et al., 2001), possibly because contraception diminished spontaneity (Bettie, 2003; Kaplan, 1997) and signalled a premeditation to stigmatised sexual behaviour (Walkerdine et al., 2001). Some expressed anti-abortion sentiments (Bettie, 2003; 
Elley, 2011) that, as one author argued, may have protected them from revealing their true desires to be a young parent (Arai, 2003).

Sub-theme 1d: For some young women who were academically skilful before they became pregnant, traditional education trajectories were fragile.

Authors of a longitudinal study of English girls (Walkerdine et al., 2001) posed that workingclass teens disrupted their pursuit of traditional middle-class, educational pathways because of a 'transformation of self':

The middle-class parents in the sample simply would not have tolerated the idea of anything, and certainly not pregnancy, getting in the way of educational success. This complicity between Sharon and her mother ...suggests that as much as both she and her parents were proud of her ambition, they were secretly terrified of it ...A baby was a much better known quantity. (2001, p. 208)

Similarly, in a longitudinal case study in the U.S. (Vetter et al., 2011), researchers interviewed an academically-motivated student who revealed she was pregnant in her last interview. The authors suggested that university conflicted with Jessica's desire to stay close to family, whereas her pregnancy allowed her 'to do what I want to...in education. I want to go to [community college] still, and I think me just having a baby makes me want it more' (2011, p. 202). Walkerdine (2001) argued the event of pregnancy helps resolve an internal conflict over the unknown (university) and the familiar (family), opening the possibility to pursue both parenthood and education, a combination that is largely unsupported by middle-class educational values. Adolescent parenthood is hence a 'problem' only in that it disrupts traditional, middle-class educational trajectories (Arai, 2003; Bettie, 2003; Coleman and Cater, 2006; Elley, 2011; Walkerdine et al., 2001) based on the assumption that parenthood and education are incompatible. However, as reported by studies that compared pre- and post-pregnancy education, schools are capable of supporting parenting and education simultaneously (Dawson and Hosie, 2005; Erdmans, 2012). 
Sub-theme le: For young mothers, becoming a parent validated a meaningful and legitimate pathway to adulthood.

Most parenting teens in the studies did not view young parenthood as 'irresponsible,' rather chose parenthood as a legitimate life pathway. Whether pregnancy was planned or the result of unintended pregnancy, participants framed young parenthood as a meaningful route to adult status (Arai, 2003; Bettie, 2003; Biggs et al., 2013; Coleman and Cater, 2006; Davidson, 2015; Erdmans and Black, 2015; Minnis et al., 2013; Smith and Roberts, 2011).

Several studies revealed that many young parents had already been forced to 'grow up quickly' by assuming adult responsibilities before pregnancy occurred, such as caring for relatives or taking on financial responsibilities (Arai, 2003; Coleman and Cater, 2006; Erdmans and Black, 2015; Minnis et al., 2013; Vetter et al., 2011). Arai (2003) argued some teens were thrust into early maturity because of traumatic childhood experiences. Parenthood was one component in a set of trajectories that defined adulthood, where having a baby validated their maturity rather than marking the end of childhood (Coleman and Cater, 2006; Erdmans and Black, 2015). Young women pursued meaningful and socially beneficial trajectories in accordance with their views on development into adulthood.

\section{Meta-theme 2: Young women's experiences of school and education}

In the second meta-theme, reciprocal translation revealed that adoption and maintenance of young women's educational and life trajectories were shaped by structural and relational factors described through stories and examples of school experiences.

Sub-theme 2a: School values are not culturally representative of young women's identities. Young women across studies expressed multiple identities based on their racial or ethnic background, country of origin, socioeconomic status and social roles that shaped their attachment and response to school (Algert, 2000; Biggs et al., 2013; Erdmans, 2012; Erdmans and Black, 2015; Kaplan, 1997; Minnis et al., 2013; Noone et al., 2014; Vetter et al., 2011). Youth of colour reported social isolation and discrimination when attending schools primarily composed of white teachers and students (Algert, 2000; Erdmans and Black, 2015; Vetter et al., 2011). They indicated their identities were not reflected in school staffing or curriculum (Gilbert, 2011; Kaplan, 1997; Smith and Roberts, 2011; Vetter et al., 2011), and schools did not adequately 
highlight the successes of black or Latinx students (Bettie, 2003; Gilbert, 2011). In studies exploring pregnancy among immigrant teens, youth and their families valued education but considered it unattainable. Language barriers impacted their grades and caused them embarrassment (Biggs et al., 2013; Erdmans, 2012; Minnis et al., 2013), preventing participation in school activities (Biggs et al., 2013). For some, migration patterns between the U.S. and their parents' country of origin caused significant absences (Erdmans and Black, 2015), the academic effects of which were exacerbated by inconsistent teaching practices and a lack of support for English Language Learners (Erdmans, 2012).

Authors reported that broader development opportunities, such as sports and after-school programmes, might increase attachment to school and motivate young people to avoid pregnancy (Childs et al., 2015; Gilbert, 2011; Martyn and Hutchinson, 2001). However, young women reported financial and cultural barriers that prevented their participation, including academic or cost requirements (Gilbert, 2011). Some students perceived that certain clubs did not welcome youth of colour (Noone et al., 2014).

\section{Sub-theme 2b: School sanctions on students' autonomy marginalise adolescents} sympathetic to young parenthood from school and education.

Reciprocal translation revealed the development of autonomy was important to young people across studies and pregnancy status. Adolescents with commitment to school expressed their autonomy in opposition to social stereotypes or identities that might jeopardise their educational aspirations (Elley, 2011; Martyn and Hutchinson, 2001; Vetter et al., 2011), such as declaring their educational and sexual independence from male dominance: 'for women, there needs to be self-esteem classes and “you don't need a man" classes, you can do for yourself” (Martyn and Hutchinson, 2001, p. 246).

For teens with weak attachment to school, educational systems or trajectories were not a source of autonomy, and detracted from established adult roles. Young mothers across several studies indicated that school prior to pregnancy conflicted with their desire for independence (Erdmans and Black, 2015; Tabi, 1999): 'Julie... fought against the structures of confining adolescence and asserted her independence from adults... "I don't like people telling me what I have to do... I want to do what I want to do, not what they want me to do"'(2015, p. 170). Several young mothers preferred post-pregnancy education because students 'were in control of 
their own choices' (Dawson and Hosie, 2005, p. 79) and the school allowed them to express their identities as adults and parents (Erdmans, 2012; Vetter et al., 2011).

When management of their education was constrained, young women asserted their independence by controlling their school and life experiences in ways they were able, such as truanting (Bettie, 2003; Vetter et al., 2011), dropping out (Biggs et al., 2013; Erdmans, 2012; Erdmans and Black, 2015) and becoming a parent (Coleman and Cater, 2006). Negative school responses to these assertions of autonomy further weakened fragile relationships with education. Because they viewed young parenthood as incompatible with school values (Bettie, 2003; Tabi, 1999), some schools sought to enforce 'appropriate' forms of autonomy (Bettie, 2003; Erdmans, 2012; Vetter et al., 2011) by putting young mothers " back in their place"... to recenter attention on the success of students who could and did follow the institutional ideals' (Bettie, 2003, pp. $71-72)$.

Sub-theme 2c: Teachers' explicit and implicit messages impact young people's expectations of future education and career.

Relationships with teachers featured prominently in young people's narratives (Agogbuo, 2006; Charmaraman and McKamey, 2011; Davidson, 2015; Dawson and Hosie, 2005; Erdmans, 2012; Erdmans and Black, 2015; Gilbert, 2011; Jones and Norton, 2007; Kaplan, 1997; Vetter et al., 2011; Willemsen and DeJaeghere, 2015; Zachry, 2005). Teens with poor attachment to school reported teachers were inaccessible (Dawson and Hosie, 2005; Erdmans, 2012; Erdmans and Black, 2015; Zachry, 2005) or perceived that teachers favoured white students or those more likely to attend college (Erdmans and Black, 2015; Vetter et al., 2011). They were, therefore, less inclined to engage: 'If you didn't show nothing to me or you didn't try to make any effort for me, I wouldn't make no effort for you'(Erdmans and Black, 2015, p. 144).

Lowered expectations of future education and career were reflected in teacher expectations (Davidson, 2015; Erdmans, 2012; Kaplan, 1997; Vetter et al., 2011), including explicit messages - 'why don't you just look for a job' (Erdmans and Black, 2015, p. 163), and indirect signals that their education was not important: 'my science teacher... let me skip' (2015, p. 164). Young people also received racialised messages that they were expected to 'end up on welfare' (Kaplan, 1997, p. 30) or were 'not smart enough to get an education' (Vetter et al., 
2011, p. 194). In one study, authors highlighted a teen whose high aspirations were not sufficient to overcome lowered expectations:

Even as she voiced these plans [to become a social worker], Juliana pointed out, more than once, that she was 'a troublemaker', observing that (white middle-class) teachers at Morton had described her this way... I asked her where she thought she would be in five years. 'Probably pregnant!' she said. 'Everybody thinks I'm going to get pregnant.' (Davidson, 2015, p. 398)

Several studies suggested positive connections to teachers but left these experiences largely unexplored (Algert, 2000; Charmaraman and McKamey, 2011; Gilbert, 2011). In one study, a teen who was not pregnant or parenting described how she assumed 'only white people with money could go to college' (Algert, 2000, p. 163) until she spoke with the school counsellor (who was also Latinx), prompting her to start 'doing all my school work and... getting all my credits' (2000, p. 157).

\section{Sub-theme 2d: Academic curriculum and support did not match student needs,} perpetuating cycles of absences and academic failure.

Many pregnant and parenting teens described the school curriculum as boring and irrelevant (Coleman and Cater, 2006; Erdmans, 2012; Erdmans and Black, 2015; Kaplan, 1997; TrustySmith, 2013; Zachry, 2005). This was attributed to mundane classroom tasks; for example, one parenting teen in a special-education class was instructed to 'copy off the books' (Erdmans and Black, 2015, p. 162). The transition from lower to higher-level grades appeared to accelerate disconnection as academic challenges and school size increased (Dawson and Hosie, 2005; Erdmans, 2012; Erdmans and Black, 2015; Kaplan, 1997; Trusty-Smith, 2013; Zachry, 2005):

"Until eighth grade I was smart, but once I hit high school and so much people around me, my head just got - I don’t know where it went." In smaller elementary school classes, “you could raise your hand and you could say, 'Mister, could you help me with this?' But you can't really do that'" in larger high schools. (Erdmans, 2012, p. 61)

Disconnection was often manifested through truancy, sometimes the result of problems outside of school, such as circular migration (Erdmans and Black, 2015), parental illness (Minnis et al., 
2013) and mental-health problems stemming from family disputes and sexual abuse (Erdmans and Black, 2015; Kaplan, 1997). Others truanted to hang out with friends (Erdmans and Black, 2015; Kaplan, 1997; Zachry, 2005):

\begin{abstract}
"Sixth and seventh grade was hard but I was able to manage it. Then eighth grade is like when ... I fell behind." She repeated eighth grade but she "skipped all the time and then started not wanting to go to school" because she could not do the work: "I tried my hardest and it seemed like the harder I tried, the less grade I got." (Erdmans and Black, 2015, pp. 166-67)
\end{abstract}

This example illustrates that attendance both reflected and compounded academic problems and perpetuated cycles of detachment from school. Multiple studies reported that young mothers were suspended as a punishment for truancy, increasing the time young people spent away from school (Erdmans, 2012; Erdmans and Black, 2015; Vetter et al., 2011).

\title{
Discussion
}

This review sought to advance understanding of how young women's experiences in education and school influence their sexual behaviours, pregnancy and parenting decisions. Synthesis of 28 qualitative studies revealed that young women's life trajectories were shaped by their commitment to school values and their expectations for academic achievement and higher education. These aspirations are informed by their perceptions of how education or parenthood would help them achieve adulthood status. Young people indicated multiple ways in which schools shaped their commitment, including whether school values align with their broader environment and experiences, how students were treated and supported by teachers, and the extent to which the curriculum was relevant and engaging.

The finding that many young mothers have weak attachments to school prior to pregnancy challenges the assumption that adolescent pregnancy is the primary reason for school dropout (Basch, 2011) and supports research that suggests young people's limited educational and career opportunities are the result of social disadvantage, of which adolescent pregnancy is only one component (Harden et al., 2009; Kearney and Levine, 2012). It also highlights the importance of school as an upstream influence on adolescent sexual health, and not just a setting for sex and relationships education (SRE) (Viner et al., 2012). 
The findings of this review support Markham and Aveyard's (2003) theory of human functioning and school organisation (described earlier) that students' commitment to schools' instructional and regulatory orders increase their capacity for practical reasoning and affiliation, which influence their behaviour and future health. The theory provides a framework for examining the impact of school and education experiences on student health.

\section{School Commitment and Pregnancy Outcomes}

Findings on students with strong educational trajectories align with Markham and Aveyard's definition of 'committed' students devoted to achieving higher education. Many students who became young parents lacked commitment to school prior to pregnancy. They may be 'detached', rejecting the rigidity of school values on non-educational trajectories, or 'estranged', because their academic abilities cannot support their desire for educational achievement. In some cases, deficits in support and cycles of disengagement 'alienated' young people because they lacked both the skill and desire to succeed in school. Detached, estranged or alienated youth might actively choose early parenthood. Others were ambivalent about planning or preventing pregnancy, for example prioritising relationship satisfaction over risk of pregnancy, and becoming pregnant via inconsistent contraceptive use. It is difficult to distinguish between these latter groups as adolescent parenthood is often stigmatised within school culture and youth may not reveal their true intentions to researchers. Young parents in these studies, however, did not demonstrate deficits in practical reasoning or affiliation as Markham and Aveyard would posit. Instead, they chose or adapted to their role as parents, because of benefits to their status as adults and limited costs to future education or career.

\section{School Community Boundaries}

Markham and Aveyard (2003) suggest that schools can increase student commitment by developing shared values with the broader community. Restorative practices, which the U.S. and U.K. have increasingly adopted, might be used to re-engage detached and alienated students who experience social disadvantage by focusing on nurturing relationships in response to undesirable behaviour, such as truancy (Fronius et al., 2016). School-based wellness centres are promising interventions for addressing various health issues affecting school engagement and learning (Knopf et al., 2016). 
Students in the studies reviewed reported racial discrimination through school policies and teaching practices. A mixed-methods study on the effects of teacher race on pregnancy outcomes has found that an increased proportion of black teachers was negatively associated with pregnancy among black students. The greater presence of black teachers may strengthen teacher-student relationships and improve the school's ability to address the needs of black students (Atkins and Wilkins, 2013). This resonates with findings in our review that young people reported their identities were not represented positively in schools where young parenthood was common.

Studies reported messages from school on acceptable forms of adulthood and autonomy, which ignored or discouraged adolescent parenthood. Young people created their own social spaces based on socioeconomic status and ethnicity within middle-class schools that validated young parenthood as a legitimate pathway to adult status and independence (Bettie, 2003). This resonates with Willis's work on how working-class boys in 1970s British schools responded to the middle-class school culture by asserting their own working-class culture (Willis, 1977). Pound et al's (2016) recent review on young people's views on SRE suggests that schools' inability to accept adolescent sexual activity, of which teen pregnancy is the visible proof, affects the relevance and salience of SRE.

\section{Teacher-Student Relationships}

Markham and Aveyard (2003) suggest that strengthening teacher-student relationships facilitates capacity for practical reasoning and affiliation. Our studies offer several explanations for teacher influence on students' sexual health. Teachers' expectations based on socioeconomic status, race, ethnicity or gender may contribute to young people's own lowered self-expectations. This aligns with evidence that students with higher educational expectations and aspirations report lower rates of sexual-risk behaviour (Henderson et al., 2008; Lauritsen, 1994; Paul et al., 2000; South and Baumer, 2000; White and Warner, 2015). Young parents also reported that they preferred teachers and school staff to treat them as adults, especially when they had already adopted adult responsibilities at home. In a qualitative case study on adolescent substance use, Fletcher et al (2009) similarly reported that female students perceived schools did not recognise their experiences with adult responsibilities, causing them to resent the school and teachers. 
In our review, students reported that they did not receive adequate teacher support. A recent review of state policy studies reported that higher expenditure and lower teacher-tostudent ratios were associated with lower rates of child bearing (Beltz et al., 2015). Teachers may focus their limited time on high-achieving students more likely to attend college. Other qualitative studies support similar findings that schools focused on academic attainment may discriminate against students unlikely to increase school attainment scores, leading young people to 'disinvest' from education and adopt risk behaviours (Bonell et al., 2012).

\section{Academic boundaries}

In accordance with studies reporting an association between attitude towards school and sexual behaviour (Bonell et al., 2005; Kogan et al., 2013), many young parents in this review disliked school and found it irrelevant to their lives. Markham and Aveyard (2003) theorise that schools can improve student commitment by integrating learning across subjects and involving students in development of teaching practices. Schools might encourage students to reflect on their overlapping identities within and outside of school as a part of assignments and provide more opportunity for student input and choice in curriculum content.

\section{Limitations}

The studies in this synthesis heavily represent low-income young women in high-income countries, primarily the U.S. and U.K.; only four studies interviewed middle-class teens and only three were from low- or middle-income (LMIC) countries. Subsequently, LMIC studies did not contribute greatly towards themes reported in this review. Further, most studies interviewed young parents after pregnancy and it could be difficult to distinguish experiences leading up to and after pregnancy. This review focused on school experiences prior to pregnancy and might therefore have excluded studies about experiences after parenthood or external to the school environment that may have contributed to the research question. The synthesis for this review drew mainly on interview data that might over-represent teens who chose a parenthood trajectory and might under-emphasise the extent to which poor information and random chance influence sexual health outcomes. Likewise, it is not possible to know whether factors for avoiding pregnancy identified by nonpregnant, nonparenting teens during early or middle adolescence were successful in helping them avoid pregnancy later. 
Methodological limitations include a lack of screening and quality assessment by multiple reviewers, which was attempted but ultimately not possible due to resource and time constraints. Bias was minimized by piloting the eligibility criteria and quality-assessment tool, results of which were discussed between the two authors. Twenty-eight studies were unobtainable for full-text screening, primarily because author contact was unavailable or there was no response to requests for full text. Most were theses and may have been captured in title and abstract screening as published versions. This review focused on the experiences of youth identified as female. Future reviews might explore gender differences in the role of education and school in sexual and pregnancy decision-making.

\section{Implications}

This synthesis identifies several factors in the school environment that can be examined in future studies. First, multi-level studies might further examine the impact of teacher characteristics on commitment to school and health outcomes, specifically racial composition of school staff and shared values between staff, students and their families. Second, new qualitative studies might further explore how school policies and practices alienate students who are sympathetic to young parenthood. Lastly, new interventions might seek to modify student sexual health outcomes by: improving teacher-student relationships through staff training to reduce cultural bias and improve communication with students; promoting adolescent take-up of adult roles and identities by gradually increasing flexibility and choice in learning activities; and ensuring physically and psychologically safe spaces through school policies and hiring practices that reflect the needs and values of students' communities. These interventions may target students during particularly vulnerable periods, such as the transition from middle to high school, to ensure students are supported socially and academically. Interventions should account for differences in school and student culture by involving youth in the development and implementation of programmes.

\section{Conclusion}

This is the most comprehensive synthesis exploring young women's views on school and education as they relate to sexual behaviour and pregnancy decisions. Aligned with Markham and Aveyard's theory that schools play a role in young people's health, findings suggest that adolescents' educational trajectories and sexual decisions are interrelated, and shaped by school 
experiences and relationships. Schools may support student health-promoting sexual behaviours by implementing policies and practices that improve teacher-student interactions, enabling young women's developing autonomy, and ensuring physically and psychologically safe spaces for students. 


\section{References}

Agogbuo, S.U., 2006. Girls schooling in Africa and the dilemma of reproductive health care among SubSaharan African women in the United States. ProQuest Diss. Theses.

Algert, S.J., 2000. Understanding Mexican American teens' motivations for early motherhood. ProQuest Diss. Theses.

Allen, J.P., Philliber, S., Herrling, S., Kuperminc, G.P., 1997. Preventing teen pregnancy and academic failure: experimental evaluation of a developmentally based approach. Child Dev. 68, 729-742. https://doi.org/10.1111/j.1467-8624.1997.tb04233.x

Arai, L., 2003. Low expectations, sexual attitudes and knowledge: explaining teenage pregnancy and fertility in English communities. Insights from qualitative research. Sociol. Rev. 51, 199-217. https://doi.org/10.1111/1467-954X.00415

Ashcraft, A., Fernández-Val, I., Lang, K., 2013. The consequences of teenage childbearing: consistent estimates when abortion makes miscarriage nonrandom. Econ. J. Lond. Engl. 123, 875-905. https://doi.org/10.1111/ecoj.12005

Atkins, D.N., Wilkins, V.M., 2013. Going beyond reading, writing, and arithmetic: the effects of teacher representation on teen pregnancy rates. J. Public Adm. Res. Theory 23, 771-790. https://doi.org/10.1093/jopart/mut001

Basch, C.E., 2011. Healthier students are better learners: a missing link in school reforms to close the achievement gap. J. Sch. Health 81, 593-598. https://doi.org/10.1111/j.1746-1561.2011.00632.x

Basen-Engquist, K., Coyle, K.K., Parcel, G.S., Kirby, D., Banspach, S.W., Carvajal, S.C., Baumler, E., 2001. Schoolwide effects of a multicomponent HIV, STD, and pregnancy prevention program for high school students. Health Educ Behav 28, 166-85. https://doi.org/https://doi.org/10.1177/109019810102800204

Bayer, A.M., Tsui, A.O., Hindin, M.J., 2010. Constrained choices: adolescents speak on sexuality in Peru. Cult. Health Sex. 12, 771-782. https://doi.org/10.1080/13691058.2010.488299

Beltz, M.A., Sacks, V.H., Moore, K.A., Terzian, M., 2015. State policy and teen childbearing: a review of research studies. J. Adolesc. Health Off. Publ. Soc. Adolesc. Med. 56, 130-138. https://doi.org/10.1016/j.jadohealth.2014.11.001

Bettie, J., 2003. How working-class chicas get working-class lives, in: Women without Class: Girls, Race, and Identity. University of California Press, Oakland CA, pp. 57-94.

Biggs, M.A., Combellick, S., Arons, A., Brindis, C.D., 2013. Educational barriers, social isolation, and stable romantic relationships among pregnant immigrant Latina teens. Hisp. Health Care Int. Off. J. Natl. Assoc. Hisp. Nurses 11, 38-46. https://doi.org/10.1891/1540-4153.11.1.38

Bonell, C., Allen, E., Strange, V., Copas, A., Oakley, A., Stephenson, J., Johnson, A., 2005. The effect of dislike of school on risk of teenage pregnancy: testing of hypotheses using longitudinal data from a randomised trial of sex education. J Epidemiol Community Health 59, 223-30. https://doi.org/10.1136/jech.2004.023374

Bonell, C., Fletcher, A., Sorhaindo, A., Wells, H., McKee, M., 2012. How market-oriented education policies might influence young people's health: development of a logic model from qualitative case studies in English secondary schools. J. Epidemiol. Community Health 66, e24. https://doi.org/10.1136/jech.2011.137539

Bonell, C., Harden, A., Wells, H., Jamal, F., Fletcher, A., Petticrew, M., Thomas, J., Whitehead, M., Campbell, R., Murphy, S., Moore, L., 2011. Protocol for a systematic review of the effects of schools and school-environment interventions on health: evidence mapping and syntheses. BMC Public Health 11, 453. https://doi.org/10.1186/1471-2458-11-453

Centers for Disease Control and Prevention, 2015. Youth Risk Behavior Survey data.

Charmaraman, L., McKamey, C., 2011. Urban early adolescent narratives on sexuality: accidental and intentional influences of family, peers, and the media. Sex. Res. Soc. Policy J. NSRC SR SP 8 , 253-266. https://doi.org/10.1007/s13178-011-0052-3 
Childs, G.D., Knight, C., White, R., 2015. Never-pregnant African American adolescent girls' perceptions of adolescent pregnancy. J. Pediatr. Nurs. 30, 310-320. https://doi.org/10.1016/j.pedn.2014.08.012

Coleman, D.L., Cater, S., 2006. "Planned" teenage pregnancy: perspectives of young women from disadvantaged backgrounds in England. J. Youth Stud. 9, 593-614. https://doi.org/10.1080/13676260600805721

Davidson, E., 2015. Responsible girls: the spatialized politics of feminine success and aspiration in a divided Silicon Valley, USA. Gend. Place Cult. 22, 390-404. https://doi.org/10.1080/0966369X.2013.879099

Dawson, N., Hosie, A., 2005. The education of pregnant young women and young mothers in England. University of Bristol, Bristol.

Elley, S., 2011. Young women, class and gendered heterosexuality: the implication of educational aspirations and social networks for sex education messages. Sociology 45, 413-429. https://doi.org/10.1177/0038038511399621

Erdmans, M.P., 2012. Title IX and the school experiences of pregnant and mothering students. Humanity Soc. 36, 50-75. https://doi.org/10.1177/0160597611433269

Erdmans, M.P., Black, T., 2015. Education, in: On Becoming a Teen Mom: Life before Pregnancy. University of California Press, Oakland, CA, pp. 141-175.

Evans, D., 2002. Database searches for qualitative research. J. Med. Libr. Assoc. 90, 290-293.

Finer, L.B., Zolna, M.R., 2016. Declines in unintended pregnancy in the United States, 2008-2011. N. Engl. J. Med. 374, 843-852. https://doi.org/10.1056/NEJMsa1506575

Flay, B.R., Graumlich, S., Segawa, E., Burns, J.L., Holliday, M.Y., Investigators, A.A., 2004. Effects of 2 prevention programs on high-risk behaviors among African American youth: a randomized trial. Arch Pediatr Adolesc Med 158, 377-84. https://doi.org/10.1001/archpedi.158.4.377

Flemming, K., Briggs, M., 2007. Electronic searching to locate qualitative research: evaluation of three strategies. J. Adv. Nurs. 57, 95-100. https://doi.org/10.1111/j.1365-2648.2006.04083.x

Fletcher, A., Bonell, C., Rhodes, T., 2009. New counter- school cultures: female students' drug use at a high- achieving secondary school. Br. J. Sociol. Educ. 30, 549-562. https://doi.org/10.1080/01425690903101049

Fletcher, J.M., Wolfe, B.L., 2009. Education and labor market consequences of teenage childbearing: evidence using the timing of pregnancy outcomes and community fixed effects. J. Hum. Resour. $44,303-325$.

Freudenberg, N., Ruglis, J., 2007. Reframing school dropout as a public health issue. Prev Chronic Dis 4.

Fronius, T., Persson, H., Guckenberg, S., Hurley, N., Petrosino, A., 2016. Restorative justice in U.S. schools: a research review. WestEd.

Gilbert, N., 2011. Puerto Rican teens' perceptions of teen pregnancy and births in Holyoke, Massachusetts. Dissertations 369.

Graham, H., McDermott, E., 2005. Qualitative research and the evidence base of policy: insights from studies of teenage mothers in the UK. J. Soc. Policy 35, 21. https://doi.org/10.1017/S0047279405009360

Green, J., Thorogood, N., 2013. Qualitative methods for health research, Third Edition edition. ed. SAGE Publications Ltd, Los Angeles.

Harden, A., Brunton, G., Fletcher, A., Oakley, A., 2009. Teenage pregnancy and social disadvantage: systematic review integrating controlled trials and qualitative studies. BMJ 339, b4254-b4254. https://doi.org/10.1136/bmj.b4254

Henderson, M., Butcher, I., Wight, D., Williamson, L., Raab, G., 2008. What explains between-school differences in rates of sexual experience? BMC Public Health 8, 53. https://doi.org/10.1186/14712458-8-53

Hoskins, B., 2001. Tales of the intimate: Exploring young people's accounts of sexual practice (Thesis). School of Social Sciences Theses. 
Jamal, F., Fletcher, A., Harden, A., Wells, H., Thomas, J., Bonell, C., 2013. The school environment and student health: a systematic review and meta-ethnography of qualitative research. BMC Public Health 13, 798. https://doi.org/10.1186/1471-2458-13-798

Jones, S., Norton, B., 2007. On the limits of sexual health literacy: insights from Ugandan schoolgirls. Diaspora Indig. Minor. Educ. 1, 285-305. https://doi.org/10.1080/15595690701563998

Kaftarian, S., Robertson, E., Compton, W., Davis, B.W., Volkow, N., Robinson, E., 2004. Blending prevention research and practice in schools: critical issues and suggestions. Prev Sci 5, 1-3. https://doi.org/https://doi.org/10.1023/B:PREV.0000013975.74774.bc

Kaplan, E.B., 1997. Tough times: Susan Carter, in: Not Our Kind of Girl: Unravelling the Myths of Black Teenage Motherhood. University of California Press, Oakland CA, pp. 27-47.

Kearney, M.S., Levine, P.B., 2012. Why is the teen birth rate in the United States so high and why does it matter? J. Econ. Perspect. J. Am. Econ. Assoc. 26, 141-166.

Knopf, J.A., Finnie, R.K.C., Peng, Y., Hahn, R.A., Truman, B.I., Vernon-Smiley, M., Johnson, V.C., Johnson, R.L., Fielding, J.E., Muntaner, C., Hunt, P.C., Jones, C.P., Fullilove, M.T., 2016. School-based health centers to advance health equity. Am. J. Prev. Med. 51, 114-126. https://doi.org/10.1016/j.amepre.2016.01.009

Kogan, S.M., Cho, J., Allen, K., Lei, M.K., Beach, S.R., Gibbons, F.X., Simons, L.G., Simons, R.L., Brody, G.H., 2013. Avoiding adolescent pregnancy: a longitudinal analysis of African-American youth. J Adolesc Health 53, 14-20. https://doi.org/10.1016/j.jadohealth.2013.01.024

Koh, H., 2014. The Teen Pregnancy Prevention Program: an evidence-based public health program model. J. Adolesc. Health 54, S1-S2. https://doi.org/10.1016/j.jadohealth.2013.12.031

Lauritsen, J., 1994. Explaining race and gender differences in adolescent sexual-behavior. Soc. Forces 72, 859-84. https://doi.org/https://doi.org/10.1093/sf/72.3.859

Markham, C.M., Lormand, D., Gloppen, K.M., Peskin, M.F., Flores, B., Low, B., House, L.D., 2010. Connectedness as a predictor of sexual and reproductive health outcomes for youth. J Adolesc Health 46, S23-41. https://doi.org/10.1016/j.jadohealth.2009.11.214

Markham, W.A., Aveyard, P., 2003. A new theory of health promoting schools based on human functioning, school organisation and pedagogic practice. Soc Sci Med 56, 1209-20.

Martin, J., Hamilton, B.E., Osterman, M.J.K., Curtin, S.C., Matthews, T.J., 2015. Births: final data for 2013. Natl. Vital Stat. Rep. 64.

Martyn, K.K., Hutchinson, S.A., 2001. Low-income African American adolescents who avoid pregnancy: tough girls who rewrite negative scripts. Qual. Health Res. 11, 238-256. https://doi.org/https://doi.org/10.1177/104973201129119073

Minnis, A.M., Marchi, K., Ralph, L., Biggs, M.A., Schwartz, S., Arons, A., Brindis, C.D., Braveman, P., 2013. Limited socioeconomic opportunities and Latina teen childbearing: a qualitative study of family and structural factors affecting future expectations. J. Immigr. Minor. Health Cent. Minor. Public Health 15, 334-340. https://doi.org/10.1007/s10903-012-9653-z

Muennig, P., Woolf, S.H., 2007. Health and economic benefits of reducing the number of students per classroom in US primary schools. Am. J. Public Health 97, 2020-2027. https://doi.org/10.2105/AJPH.2006.105478

$\mathrm{Ng}$, A., Kaye, K., 2015. Sex in the (non)city: teen childbearing in rural America. Power to Decide, Washington, DC.

Noblit, G.W., Hare, R.D., 1988. Meta-ethnography, Qualitative Research Methods. SAGE Publications Inc, Newbury Park, CA.

Noone, J., Allen, T.L., Sullivan, M., McKenzie, G., Esqueda, T., Ibarra, N., 2014. Escuchando a Nuestros Jóvenes: a latino youth photovoice project on teen pregnancy. Hisp. Health Care Int. Off. J. Natl. Assoc. Hisp. Nurses 12, 63-70. https://doi.org/10.1891/1540-4153.12.2.63

Patton, G.C., Bond, L., Carlin, J.B., Thomas, L., Butler, H., Glover, S., Catalano, R., Bowes, G., 2006. Promoting social inclusion in schools: a group-randomized trial of effects on student health risk 
behavior and well-being. Am J Public Health 96, 1582-7.

https://doi.org/10.2105/AJPH.2004.047399

Patton, G.C., Sawyer, S.M., Santelli, J.S., Ross, D.A., Afifi, R., Allen, N.B., Arora, M., Azzopardi, P., Baldwin, W., Bonell, C., Kakuma, R., Kennedy, E., Mahon, J., McGovern, T., Mokdad, A.H., Patel, V., Petroni, S., Reavley, N., Taiwo, K., Waldfogel, J., Wickremarathne, D., Barroso, C., Bhutta, Z., Fatusi, A.O., Mattoo, A., Diers, J., Fang, J., Ferguson, J., Ssewamala, F., Viner, R.M., 2016. Our future: a Lancet commission on adolescent health and wellbeing. The Lancet 387 , 2423-2478. https://doi.org/10.1016/S0140-6736(16)00579-1

Paul, C., Fitzjohn, J., Herbison, P., Dickson, N., 2000. The determinants of sexual intercourse before age 16. J Adolesc Health 27, 136-47. https://doi.org/https://doi.org/10.1016/S1054-139X(99)00095-6

Penman-Aguilar, A., Carter, M., Snead, M.C., Kourtis, A.P., 2013. Socioeconomic disadvantage as a social determinant of teen childbearing in the U.S. Public Health Rep. 128, 5-22. https://doi.org/https://doi.org/10.1177/00333549131282S102

Peterson, A., Bonell, C., 2016. A protocol for a systematic review examining the influence of school experiences and educational assets on sexual health and teenage pregnancy: a qualitative synthesis. PROSPERO.

Philliber, S., Williams Kaye, J., Herrling, S., West, E., 2002. Preventing pregnancy and improving health care access among teenagers: an evaluation of the Children's Aid Society-Carrera Program. Perspect. Sex. Reprod. Health 34.

Pound, P., Langford, R., Campbell, R., 2016. What do young people think about their school-based sex and relationship education? A qualitative synthesis of young people's views and experiences. BMJ Open 6, e011329. https://doi.org/10.1136/bmjopen-2016-011329

Rees, R., Caird, J., Stansfield, C, Dickson, K, Kavanagh, J., Thomas, J., 2010. Young people's views relating to obesity and body size, shape and weight: protocol for a systematic review. EPPICentre, Social Sciences Research Unit, Institute of Education, London.

Rink, E., Tricker, R., Harvey, S.M., 2007. Onset of sexual intercourse among female adolescents: the influence of perceptions, depression, and ecological factors. J Adolesc Health 41, 398-406. https://doi.org/10.1016/j.jadohealth.2007.04.017

Rose, G., 1992. Rose's strategy of preventive medicine. Oxford University Press, Oxford.

Sawyer, S.M., Afifi, R.A., Bearinger, L.H., Blakemore, S.-J., Dick, B., Ezeh, A.C., Patton, G.C., 2012. Adolescence: a foundation for future health. The Lancet 379, 1630-1640. https://doi.org/https://doi.org/10.1016/S0140-6736(12)60072-5

Sedgh, G., Finer, L.B., Bankole, A., Eilers, M.A., Singh, S., 2015. Adolescent pregnancy, birth, and abortion rates across countries: levels and recent trends. J. Adolesc. Health 56, 223-230. https://doi.org/10.1016/j.jadohealth.2014.09.007

Shepherd, J, Kavanagh, J, Picot, J, Cooper, K, Harden, A., Barnett-Page, E, Jones, J, Clegg, A, Harwell, D, Frampton, GK, Price, A, 2010. The effectiveness and cost-effectiveness of behavioural interventions for the prevention of sexually transmitted infections in young people aged 13-19: a systematic review and economic evaluation. Health Technol. Assess. 14. https://doi.org/10.3310/hta14070.

Smith, D.M., Roberts, R., 2011. Social inequality and young pregnancy: the causal attributions of young parents in London, UK. Health Place 17, 1054-1060. https://doi.org/10.1016/j.healthplace.2011.06.009

Sonfield, A., Hasstedt, K., Kavanaugh, M.L., Anderson, R., 2013. The social and economic benefits of women's ability to determine whether and when to have children. Guttmacher Institute, New York.

South, S., Baumer, E., 2000. Deciphering community and race effects on adolescent premarital childbearing. Soc. Forces 78, 1379-407. https://doi.org/https://doi.org/10.1093/sf/78.4.1379 
Spear, H.J., Lock, S., 2003. Qualitative research on adolescent pregnancy: a descriptive review and analysis. J. Pediatr. Nurs. 18, 397-408. https://doi.org/https://doi.org/10.1016/S08825963(03)00160-X

Tabi, M.M., 1999. Validation of a model to reduce teenage pregnancy. ProQuest Dissertations and.

Thomas, J, Brunton, J., Graziosi S, 2010. EPPI Reviewer 4.0: software for research synthesis.

Thomas, J., Harden, A., 2008. Methods for the thematic synthesis of qualitative research in systematic reviews. BMC Med. Res. Methodol. 8, 45. https://doi.org/10.1186/1471-2288-8-45

Trusty-Smith, B., 2013. The optimism to overcome: Educational beliefs and strategies of resilience among African American college graduates who are former teenage mothers. ProQuest Dissertations and Theses.

Vetter, A.M., Fairbanks, C., Ariail, M., 2011. "Crazyghettosmart": a case study in Latina identities. Int. J. Qual. Stud. Educ. 24, 185-207. https://doi.org/10.1080/09518391003641890

Viner, R., Ozer, E.M., Denny, S., Marmot, M., Resnick, M., Fatusi, A., Currie, C., 2012. Adolescence and the social determinants of health. Lancet 379, 1641-52.

Walkerdine, V., Lucey, H., Melody, J., 2001. Pregnancy and young motherhood, in: Growing up Girl: Psychosocial Explorations of Gender and Class. Palgrave, Hampshire UK, pp. 187-210.

White, C.N., Warner, L.A., 2015. Influence of family and school-level factors on age of sexual initiation. J. Adolesc. Health 56, 231-237. https://doi.org/10.1016/j.jadohealth.2014.09.017

Willemsen, L.W., DeJaeghere, J., 2015. Learning to negotiate sexual relationships: a girls' school in Tanzania as a restrictive and agentic site. Gend. Educ. 27, 183-197. https://doi.org/10.1080/09540253.2015.1006586

Willis, P., 1977. Learning to Labor. Columbia University Press, New York, NY.

Wong, S.S.-L., Wilczynski, N.L., Haynes, R.B., Hedges Team, 2004. Developing optimal search strategies for detecting clinically relevant qualitative studies in MEDLINE. Stud. Health Technol. Inform. 107, 311-316.

Zachry, E.M., 2005. Getting my education: teen mothers' experiences in school before and after motherhood. Teach. Coll. Rec. 107, 2566-2598. https://doi.org/10.1111/j.1467-

9620.2005.00629.x 


\begin{tabular}{|c|c|c|c|c|c|c|c|}
\hline Author & Study Aim & Study Location & $\begin{array}{l}\text { Sample } \\
\text { Size }\end{array}$ & $\begin{array}{c}\text { Age } \\
\text { Range }\end{array}$ & $\begin{array}{c}\text { Socio Economic } \\
\text { Status }\end{array}$ & Ethnicity/ Race & $\begin{array}{c}\text { Pregnancy or } \\
\text { Parenthood } \\
\text { Status } \\
\end{array}$ \\
\hline (Algert, 2000) & $\begin{array}{l}\text { To explore the } \\
\text { hypothesis that } \\
\text { acculturated, low } \\
\text { income Mexican- } \\
\text { American teen } \\
\text { mothers mirror the } \\
\text { values and } \\
\text { behaviours of } \\
\text { their Anglo- } \\
\text { American } \\
\text { counterparts. }\end{array}$ & $\begin{array}{l}\text { USA } \\
\text { San Diego, CA }\end{array}$ & 63 & $\begin{array}{l}\sim 16 \\
\text { years }\end{array}$ & Low-income & $\begin{array}{l}\text { Mexican- } \\
\text { American and } \\
\text { Anglo-American }\end{array}$ & $\begin{array}{l}\text { Pregnant/ } \\
\text { parenting and } \\
\text { nonpregnant/ } \\
\text { nonparenting }\end{array}$ \\
\hline (Arai, 2003) & $\begin{array}{l}\text { To explore how } \\
\text { well policy } \\
\text { explanations for } \\
\text { early pregnancy } \\
\text { match accounts of } \\
\text { young mothers in } \\
\text { diverse English } \\
\text { communities. }\end{array}$ & $\begin{array}{l}\text { UK } \\
\text { London, } \\
\text { Northumberland, } \\
\text { and Manchester }\end{array}$ & 12 & $\begin{array}{l}\text { Not } \\
\text { stated }\end{array}$ & Working-class & Not stated & $\begin{array}{l}\text { Parenting before } \\
20 \text { years old }\end{array}$ \\
\hline
\end{tabular}




\begin{tabular}{|c|c|c|c|c|c|c|c|}
\hline $\begin{array}{l}\text { (Bayer et al., } \\
\text { 2010) }\end{array}$ & $\begin{array}{l}\text { To uncover the } \\
\text { role of global } \\
\text { transitions in } \\
\text { sexual behaviour } \\
\text { of Peruvian } \\
\text { adolescents. }\end{array}$ & $\begin{array}{l}\text { Peru } \\
\text { Pampas }\end{array}$ & 20 & $\begin{array}{l}12-17 \\
\text { years }\end{array}$ & $\begin{array}{l}\text { Recruited from } \\
\text { low-income area }\end{array}$ & Not stated & Not stated \\
\hline (Bettie, 2003) & $\begin{array}{l}\text { To study } \\
\text { perceptions of } \\
\text { social differences } \\
\text { at school and } \\
\text { possibilities of } \\
\text { future by girls of } \\
\text { different classes } \\
\text { and race/ethnic } \\
\text { locations. }\end{array}$ & $\begin{array}{l}\text { USA } \\
\text { Midwestern } \\
\text { farming town }\end{array}$ & $\sim 60$ & $\begin{array}{l}\text { High } \\
\text { school } \\
\text { age }\end{array}$ & $\begin{array}{l}\text { Working- and } \\
\text { middle-class }\end{array}$ & $\begin{array}{l}\text { White and } \\
\text { Mexican- } \\
\text { American }\end{array}$ & Not stated \\
\hline $\begin{array}{l}\text { (Charmaraman } \\
\text { and } \\
\text { McKamey, } \\
\text { 2011) }\end{array}$ & $\begin{array}{l}\text { To examine } \\
\text { contexts and } \\
\text { situations in } \\
\text { which urban } \\
\text { adolescents } \\
\text { gather/explore } \\
\text { information about } \\
\text { relationships and } \\
\text { sexuality. }\end{array}$ & $\begin{array}{l}\text { USA } \\
\text { Northeastern } \\
\text { Region }\end{array}$ & 23 & 6 th grade & Not stated & $\begin{array}{l}\text { Black, Latino/a, } \\
\text { Multiracial, and } \\
\text { White }\end{array}$ & Not stated \\
\hline
\end{tabular}




\begin{tabular}{|c|c|c|c|c|c|c|c|}
\hline $\begin{array}{l}\text { (Childs et al., } \\
\text { 2015) }\end{array}$ & $\begin{array}{l}\text { To explore the } \\
\text { social context in } \\
\text { which never- } \\
\text { pregnant African- } \\
\text { American } \\
\text { adolescent girls, } \\
\text { aged } 12-14 \text {, form } \\
\text { opinions about } \\
\text { adolescent } \\
\text { pregnancy. }\end{array}$ & $\begin{array}{l}\text { USA } \\
\text { Southeastern } \\
\text { Metropolitan } \\
\text { City }\end{array}$ & 64 & $\begin{array}{l}12-14 \\
\text { years }\end{array}$ & $\begin{array}{l}60 \% \text { of } \\
\text { participants } \\
\text { received free or } \\
\text { reduced lunch }\end{array}$ & $\begin{array}{l}\text { African- } \\
\text { American }\end{array}$ & $\begin{array}{l}\text { Not pregnant or } \\
\text { parenting }\end{array}$ \\
\hline $\begin{array}{l}\text { (Coleman and } \\
\text { Cater, 2006) }\end{array}$ & $\begin{array}{l}\text { To explore } \\
\text { decisions behind } \\
\text { 'planned' teenage } \\
\text { pregnancy. }\end{array}$ & $\begin{array}{l}\text { UK } \\
\text { E and W Sussex, } \\
\text { Derbyshire, } \\
\text { Yorkshire, } \\
\text { Lancashire, } \\
\text { Great Yarmouth } \\
\text { and Cornwall }\end{array}$ & 41 & $\begin{array}{l}13-21 \\
\text { years }\end{array}$ & $\begin{array}{l}\text { Most living in } \\
\text { low-income areas }\end{array}$ & White-British & $\begin{array}{l}\text { Pregnant or } \\
\text { parenting a child } \\
\text { under } 1 \text { year old }\end{array}$ \\
\hline $\begin{array}{l}\text { (Davidson, } \\
2015)\end{array}$ & $\begin{array}{l}\text { To examine } \\
\text { working-class } \\
\text { Latina and } \\
\text { middle-class white } \\
\text { girls' narratives of } \\
\text { aspiration and } \\
\text { expressions of } \\
\text { self-cultivation in } \\
\text { Silicon Valley, } \\
\text { USA. }\end{array}$ & $\begin{array}{l}\text { USA } \\
\text { San Jose and } \\
\text { Palo Alto, CA }\end{array}$ & $\begin{array}{l}\text { Not } \\
\text { stated }\end{array}$ & $\begin{array}{l}\text { High } \\
\text { school } \\
\text { age }\end{array}$ & $\begin{array}{l}\text { Middle-class and } \\
\text { working-class, } \\
\text { low-income }\end{array}$ & White and Latina & Not stated \\
\hline
\end{tabular}




\begin{tabular}{|c|c|c|c|c|c|c|c|}
\hline $\begin{array}{l}\text { (Dawson and } \\
\text { Hosie, 2005) }\end{array}$ & $\begin{array}{l}\text { To identify what } \\
\text { factors determined } \\
\text { both academic and } \\
\text { broader success } \\
\text { for pregnant } \\
\text { young women and } \\
\text { young mothers. }\end{array}$ & $\begin{array}{l}\text { UK } \\
10 \text { Local } \\
\text { Education } \\
\text { Agencies in } \\
\text { England }\end{array}$ & 93 & $\begin{array}{l}\text { Not } \\
\text { stated }\end{array}$ & $\begin{array}{l}\text { Living in areas } \\
\text { with varying } \\
\text { levels of } \\
\text { deprivation }\end{array}$ & $\begin{array}{l}\text { White, Black- } \\
\text { African, Black- } \\
\text { Caribbean, } \\
\text { Bangladeshi, } \\
\text { Asian/White, } \\
\text { Other }\end{array}$ & $\begin{array}{l}\text { Pregnant or } \\
\text { parenting }\end{array}$ \\
\hline (Elley, 2011) & $\begin{array}{l}\text { To study } \\
\text { participants' views } \\
\text { of sexual and } \\
\text { relationships } \\
\text { education, } \\
\text { intimate } \\
\text { relationships, } \\
\text { educational } \\
\text { aspirations and } \\
\text { future plans. }\end{array}$ & $\begin{array}{l}\text { UK } \\
\text { Northeast } \\
\text { England }\end{array}$ & 12 & $\begin{array}{l}15-21 \\
\text { years }\end{array}$ & $\begin{array}{l}\text { Middle- and } \\
\text { working- class }\end{array}$ & Not stated & Not stated \\
\hline $\begin{array}{l}\text { (Erdmans, } \\
\text { 2012) }\end{array}$ & $\begin{array}{l}\text { To examine why } \\
\text { pregnant and } \\
\text { mothering teens } \\
\text { did or did not stay } \\
\text { in high school and } \\
\text { whether schools } \\
\text { violated Title IX } \\
\text { legislation. }\end{array}$ & $\begin{array}{l}\text { USA } \\
\text { Connecticut }\end{array}$ & 62 & $\begin{array}{l}\sim 17.9 \\
\text { years }\end{array}$ & $\begin{array}{l}93 \% \text { eligible for } \\
\text { Medicaid }\end{array}$ & $\begin{array}{l}\text { Puerto Rican, } \\
\text { White, African- } \\
\text { American, } \\
\text { Multiple races }\end{array}$ & Parenting \\
\hline $\begin{array}{l}\text { (Erdmans and } \\
\text { Black, 2015) }\end{array}$ & $\begin{array}{l}\text { To explore teen } \\
\text { moms' life stories } \\
\text { prior to } \\
\text { pregnancy. }\end{array}$ & $\begin{array}{l}\text { USA } \\
\text { Connecticut }\end{array}$ & 108 & $\begin{array}{l}13-25 \\
\text { years }\end{array}$ & $\begin{array}{l}\text { Currently } \\
\text { receiving } \\
\text { government } \\
\text { assistance }\end{array}$ & $\begin{array}{l}\text { White, Puerto } \\
\text { Rican, Black, } \\
\text { Other Latina, } \\
\text { Multiracial, } \\
\text { Asian and West } \\
\text { Indian }\end{array}$ & Parenting \\
\hline
\end{tabular}




\begin{tabular}{|c|c|c|c|c|c|c|c|}
\hline (Gilbert, 2011) & $\begin{array}{l}\text { To examine } \\
\text { perceptions held } \\
\text { by Puerto Rican } \\
\text { teens living in } \\
\text { Holyoke MA } \\
\text { about teen } \\
\text { pregnancy and } \\
\text { births. }\end{array}$ & $\begin{array}{l}\text { USA Holyoke, } \\
\text { MA }\end{array}$ & 39 & $\begin{array}{l}14-19 \\
\text { years }\end{array}$ & $\begin{array}{l}89 \% \text { of } \\
\text { participants at or } \\
\text { below poverty } \\
\text { level }\end{array}$ & Puerto Rican & $\begin{array}{l}\text { Not pregnant or } \\
\text { parenting }\end{array}$ \\
\hline $\begin{array}{l}\text { (Jones and } \\
\text { Norton, 2007) }\end{array}$ & $\begin{array}{l}\text { To explore to } \\
\text { what extent young } \\
\text { women in Uganda } \\
\text { are informed } \\
\text { about sexual } \\
\text { actions, } \\
\text { experience sexual } \\
\text { abuse and have } \\
\text { ability to embrace } \\
\text { sexuality. }\end{array}$ & $\begin{array}{l}\text { Uganda } \\
\text { Kyato Village }\end{array}$ & 15 & $\begin{array}{l}\sim 17 \\
\text { years }\end{array}$ & $\begin{array}{l}\text { Mostly low- } \\
\text { income }\end{array}$ & Not stated & Not stated \\
\hline $\begin{array}{l}\text { (Kaplan, } \\
\text { 1997) }\end{array}$ & $\begin{array}{l}\text { To delve beneath } \\
\text { the stereotypes of } \\
\text { teenage } \\
\text { motherhood and } \\
\text { reveal } \\
\text { motivations, } \\
\text { concerns and } \\
\text { strategies that } \\
\text { make the lives of }\end{array}$ & $\begin{array}{l}\text { USA } \\
\text { East Bay, CA }\end{array}$ & 32 & $\begin{array}{l}15-43 \\
\text { years }\end{array}$ & $\begin{array}{l}\text { On welfare at } \\
\text { time of interview }\end{array}$ & Black & $\begin{array}{l}\text { Parenting before } \\
19 \text { years old }\end{array}$ \\
\hline
\end{tabular}




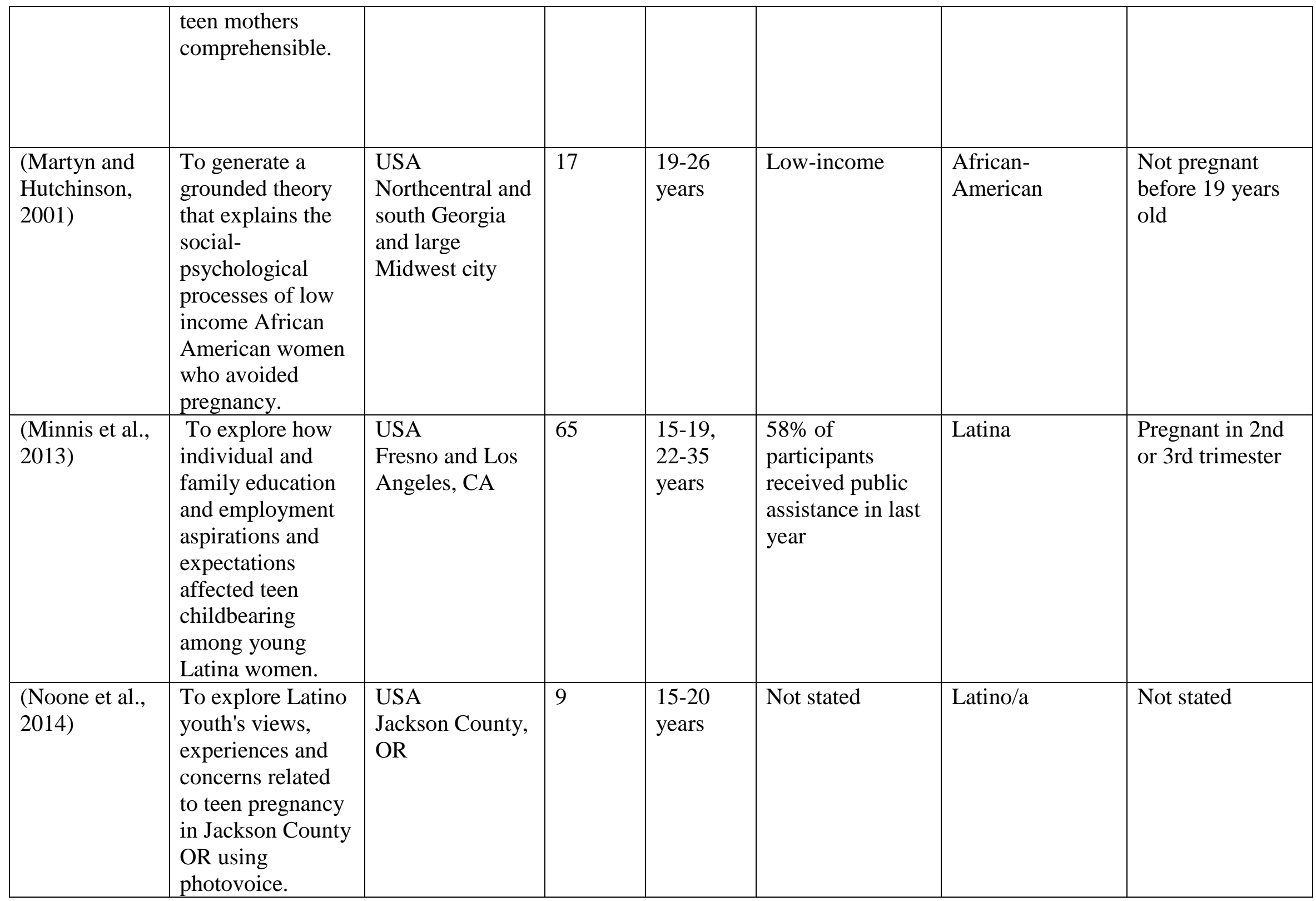




\begin{tabular}{|c|c|c|c|c|c|c|c|}
\hline $\begin{array}{l}\text { (Smith and } \\
\text { Roberts, 2011) }\end{array}$ & $\begin{array}{l}\text { To investigate } \\
\text { young parents' } \\
\text { understanding of } \\
\text { the social gradient } \\
\text { in young } \\
\text { pregnancy. }\end{array}$ & $\begin{array}{l}\text { UK } \\
\text { London }\end{array}$ & 21 & $\begin{array}{l}17-40 \\
\text { years }\end{array}$ & $\begin{array}{l}\text { Living in } \\
\text { deprived area }\end{array}$ & $\begin{array}{l}\text { White, Black, } \\
\text { Multiple Race, } \\
\text { Caribbean, } \\
\text { Albanian, Indian }\end{array}$ & $\begin{array}{l}\text { Pregnant or } \\
\text { partner } \\
\text { conceived under } \\
18 \text { years }\end{array}$ \\
\hline (Tabi, 1999) & $\begin{array}{l}\text { To improve } \\
\text { understanding of } \\
\text { educational-career } \\
\text { programme } \\
\text { effectiveness } \\
\text { among African } \\
\text { American youth. }\end{array}$ & $\begin{array}{l}\text { USA } \\
\text { Major } \\
\text { Midwestern City }\end{array}$ & 28 & $\begin{array}{l}14-18 \\
\text { years }\end{array}$ & $\begin{array}{l}\text { Recruited from } \\
\text { low-income } \\
\text { community }\end{array}$ & $\begin{array}{l}\text { African- } \\
\text { American }\end{array}$ & $\begin{array}{l}\text { Pregnant/ } \\
\text { parenting and } \\
\text { nonpregnant/ } \\
\text { nonparenting }\end{array}$ \\
\hline $\begin{array}{l}\text { (Trusty-Smith, } \\
\text { 2013) }\end{array}$ & $\begin{array}{l}\text { To explore real- } \\
\text { life experiences } \\
\text { and narratives of } \\
\text { African American, } \\
\text { former teenager } \\
\text { mothers who have } \\
\text { earned a college } \\
\text { degree. }\end{array}$ & $\begin{array}{l}\text { USA } \\
\text { Maryland, New } \\
\text { York, Georgia, } \\
\text { Alabama, and } \\
\text { Florida }\end{array}$ & 20 & $\begin{array}{l}28-59 \\
\text { years }\end{array}$ & $\begin{array}{l}\text { Working-class } \\
\text { (as child) }\end{array}$ & $\begin{array}{l}\text { African- } \\
\text { American }\end{array}$ & $\begin{array}{l}\text { Parenting } \\
\text { between 13-19 } \\
\text { years old }\end{array}$ \\
\hline $\begin{array}{l}\text { (Vetter et al., } \\
\text { 2011) }\end{array}$ & $\begin{array}{l}\text { To explore how } \\
\text { youth are subject } \\
\text { to competing and } \\
\text { conflicting } \\
\text { discourses that } \\
\text { have influenced } \\
\text { their identities. }\end{array}$ & $\begin{array}{l}\text { USA } \\
\text { Large Southwest } \\
\text { City }\end{array}$ & 1 & $\begin{array}{l}11^{\text {th }} \text { and } \\
12^{\text {th }} \\
\text { grade }\end{array}$ & $\begin{array}{l}\text { Lives in a } \\
\text { working-class } \\
\text { neighbourhood }\end{array}$ & Latina & $\begin{array}{l}\text { Pregnant (near } \\
\text { end of } \\
\text { longitudinal } \\
\text { study) }\end{array}$ \\
\hline $\begin{array}{l}\text { (Walkerdine et } \\
\text { al., 2001) }\end{array}$ & $\begin{array}{l}\text { To study the } \\
\text { complex social, } \\
\text { cultural, } \\
\text { psychological }\end{array}$ & UK & 30 & $\begin{array}{l}16 \text { and } \\
21 \text { years }\end{array}$ & $\begin{array}{l}\text { Working- and } \\
\text { middle-class }\end{array}$ & $\begin{array}{l}\text { White, African- } \\
\text { Caribbean, } \\
\text { Multiple Race, } \\
\text { Asian }\end{array}$ & $\begin{array}{l}\text { Pregnant/ } \\
\text { parenting and } \\
\text { nonpregnant/ } \\
\text { nonparenting }\end{array}$ \\
\hline
\end{tabular}




\begin{tabular}{|c|c|c|c|c|c|c|c|}
\hline & $\begin{array}{l}\text { dynamics of } \\
\text { young women. }\end{array}$ & & & & & & \\
\hline $\begin{array}{l}\text { (Willemsen } \\
\text { and } \\
\text { DeJaeghere, } \\
\text { 2015) }\end{array}$ & $\begin{array}{l}\text { To study how } \\
\text { school's } \\
\text { curriculum and } \\
\text { practices teach } \\
\text { critical and } \\
\text { transformative } \\
\text { perspectives on } \\
\text { relationships, } \\
\text { sexuality and } \\
\text { gendered futures. }\end{array}$ & Tanzania & 6 & $\begin{array}{l}\text { Not } \\
\text { stated }\end{array}$ & $\begin{array}{l}\text { Recruited from } \\
\text { school that serves } \\
\text { 'vulnerable' girls }\end{array}$ & Not stated & Not stated \\
\hline (Zachry, 2005) & $\begin{array}{l}\text { To study to } \\
\text { examine how } \\
\text { motherhood may } \\
\text { influence women's } \\
\text { self-identity and } \\
\text { perspective of } \\
\text { education. }\end{array}$ & $\begin{array}{l}\text { USA } \\
\text { Boston, MA }\end{array}$ & 9 & $\begin{array}{l}18-20 \\
\text { years }\end{array}$ & $\begin{array}{l}\text { Receiving } \\
\text { welfare } \\
\text { assistance }\end{array}$ & $\begin{array}{l}\text { Latino, Cape } \\
\text { Verdean, } \\
\text { African- } \\
\text { American, and } \\
\text { Indian }\end{array}$ & Parenting \\
\hline
\end{tabular}


Figure 1

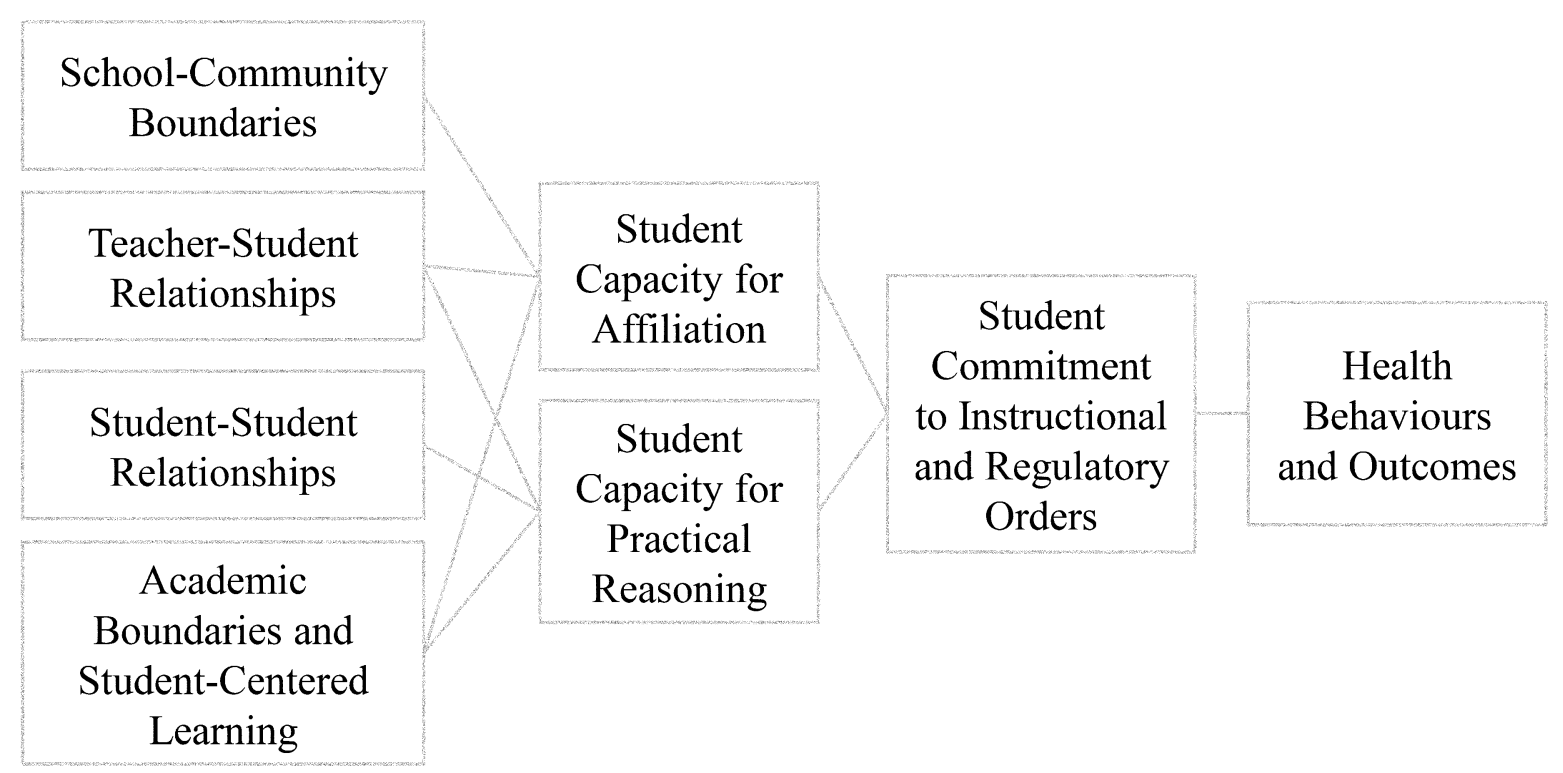


Figure 2

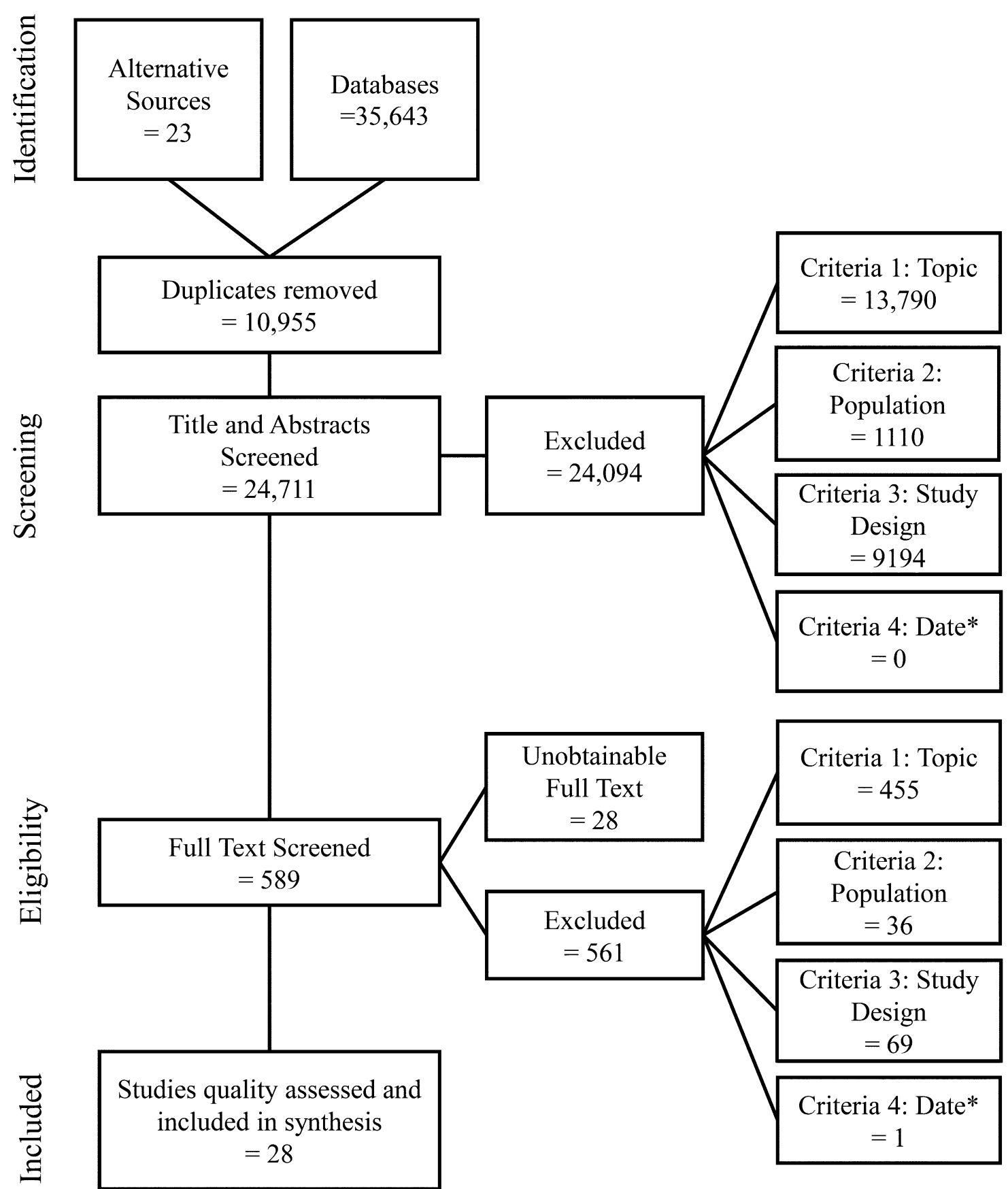

*Date was set as limit in database searches 